(c) American Dairy Science Association, 2004.

\title{
Glucose Metabolism in Lactating Cows in Response to Isoenergetic Infusions of Propionic Acid or Duodenal Glucose
}

\author{
S. Lemosquet, ${ }^{1}$ S. Rigout, ${ }^{1}$ A. Bach, ${ }^{2}$ H. Rulquin, ${ }^{1}$ and J. W. Blum ${ }^{3}$ \\ ${ }^{1}$ Unité Mixte de Recherches sur la Production du Lait, \\ Institut National de la Recherche Agronomique, \\ 35590 Saint Gilles, France \\ ${ }^{2}$ IRTA, Unidad de Ruminates, Edificio V, 08193 Bellaterra, Spain \\ ${ }^{3}$ Division of Animal Nutrition and Physiology, \\ Institute of Animals Genetics, Nutrition and Housing, \\ University of Berne, $\mathrm{CH}-3312$ Berne, Switzerland
}

\section{ABSTRACT}

A bibliographical study showed that increasing supplies of glucogenic nutrients lead to a curvilinear increase in milk and protein yield. Increased post-hepatic glucose availability may be involved in the increase in milk yield. In the present experiment, 5 dairy cows were arranged in a $5 \times 5$ Latin square design to compare the respective effects of 2 amounts of either duodenal glucose or ruminal propionic acid (C3) on glucose metabolism. Treatment consisted of a grass silage-based diet supplemented with glucogenic nutrients infused into the rumen as a mixture of volatile fatty acids (control) or C3 (6.5 and $13 \mathrm{~mol} / \mathrm{d}$ ) or as glucose (3.4 and 6.9 $\mathrm{mol} / \mathrm{d}$ ) infused into the duodenum. Treatments were isoenergetic and isonitrogenous and contained 100 and $115 \%$ of energy and protein requirements, respectively, according to the Institut National de la Recherche Agronomique. Glucose appearance rate $(\mathrm{Ra})$ tended to increase with the level of infusions of both glucogenic materials and with the high dose of duodenal glucose. Plasma insulin-like growth factor-I (IGF-I) concentration increased with the infusion of glucogenic materials compared with the control and was significantly higher with glucose than with $\mathrm{C} 3$ treatments. This experiment did not indicate whether the increased Ra was the key mechanism to increased milk yield because milk yield only tended to increase and the standard error for Ra was high. With the high dose of glucose infused into the duodenum, the $\mathrm{Ra}$ increase was greater than the increased lactose production in milk. Because of that connection, IGF-I may also be involved by favoring the glucose utilization by the mammary gland.

Received December 3, 2002.

Accepted November 8, 2003.

Corresponding author: S. Lemosquet; e-mail: lemosque@st-gilles. rennes.inra.fr.
(Key words: dairy cow, propionic acid, glucose, glucose metabolism)

Abbreviation key: BCAA = branched-chain AA, C3 = propionic acid, EAA = essential AA, GH = growth hormone, NEAA = nonessential AA, Ra = glucose appearance rate, $\mathbf{R M S E}=$ root mean square error, $\mathbf{T A A}=$ total AA.

\section{INTRODUCTION}

Glucose is essential for milk synthesis. The availability of glucose to the mammary gland has an important impact on milk yield because lactose is the major osmoregulator in mammary uptake of water. Increasing amounts of either post-ruminal glucose or ruminal propionic acid (C3) enhance both milk and protein yield in lactating dairy cows when dietary supply of postruminal starch is low, such as with grass silage diets, as reviewed by Rigout et al. (2003). Increased milk yield may result from changes in glucose supply to the mammary gland (Rigout et al., 2002b). With duodenal infusions of glucose, an increased glucose appearance rate (Ra) may be a key factor favoring an increased glucose uptake by the mammary gland and increased milk yield (Rigout et al., 2002b). However, because C3 is the major precursor for hepatic glucose production (Danfaer et al., 1995), increased glucose production may also favor increased milk yield.

The effects of post-ruminal glucose or starch infusions of several-day duration on Ra have only been measured in a few studies in lactating dairy cows (Clark et al., 1977; Knowlton et al., 1998; Rigout et al., 2002b). A significant increase in Ra was observed in response to graded amounts of glucose infused into the duodenum when cows were fed at $110 \%$ of protein requirement (Rigout et al., 2002b) or when glucose was abomasally infused at one dose in addition to casein infusion; glucose alone had no effect (Clark et al., 1977). These re- 
sults suggest that protein supply should not be limiting to increased Ra. The abomasal infusion of starch also tended to increase Ra in comparison with ruminal infusion (Knowlton et al., 1998). To our knowledge, the effect of ruminal infusion of C3 on Ra was never measured in lactating dairy cows. In other ruminants, the effect of C3 infusions on Ra differed among experiments. A significant increase in Ra was reported in nonlactating ruminants (Baird et al., 1980; Veenhuizen et al., 1988; Peiris et al., 1998), but no increase was observed in lactating ruminants (Baird et al., 1980; Casse et al., 1994; Danfaer et al., 1995). Results may also depend on the site of infusion intravenously (Baird et al., 1980; Casse et al., 1994; Danfaer et al., 1995) or ruminally (Judson and Leng, 1973; Veenhuizen et al., 1988; Peiris et al., 1998), which may change the nature and the amounts of precursors available for gluconeogenesis. When $\mathrm{C} 3$ is administered into the rumen, a part of C3 is metabolized into the rumen wall (Seal and Parker, 1994) and in comparison with intravenous infusion, only a part of the rumen C3 appears in the portal vein. However, portal appearance of lactate and alanine may increase (Seal and Parker, 1994). Lastly, results may depend on the duration of infusions, amounts infused, and on total energy intake (Casse et al., 1994). In lactating cows, the effect of ruminal C3 and duodenal glucose were never compared, but infusions of starch into the rumen had no effect on Ra or only slightly increased hepatic glucose production. Abomasal infusion of starch tended to increase Ra or increased net glucose absorption (Reynolds et al., 1997; Knowlton et al., 1998). However, if ruminal starch infusion likely increased production of ruminal propionate (Knowlton et al., 1998), then ruminal starch fermentation also produced VFA other than C3 and part of fermented C is used in the synthesis of microbial cells. The relative efficiency of glucose and C3 in increasing Ra was only compared on 2 occasions: during short-term intravenous infusion in lactating dairy cows (Baird et al., 1980) through low levels of supplementation in the digestive tract of steers (Peiris et al., 1998). However, in those treatments glucose and $\mathrm{C} 3$ were given as a supplement to the diet, and infusions were neither isomolar nor isoenergetic, which might confuse the positive effect of energy absorbed on Ra (Wieghart et al., 1986) and the specific effect of the nature of the nutrients.

Increasing amounts of C3 or glucose increased milk protein yield in parallel with milk yield (Rigout et al., 2003), suggesting that milk protein yield could be limited by glucose supply in cows receiving grass silage (Huhtanen et al., 2002). Several hypotheses on AA metabolism are proposed to explain this increased protein yield. First, increasing glucogenic materials (i.e., ruminal C3 or post-ruminal glucose) may reduce the utiliza- tion of some AA for gluconeogenesis and increase the supply and uptake of glucogenic AA to the mammary gland. This hypothesis is not likely able to explain the increased protein yield obtained with duodenal glucose infusions because these treatments did not increase the uptake of glucogenic AA by the mammary gland (Rigout et al., 2001) but increased the uptake of essential amino acids (EAA) (Rigout et al., 2001). However, a sparing effect of C3 on glucogenic AA cannot be excluded.

The objective of the current study was to compare, on an isoenergetic basis, the effects of C3 infused into the rumen and glucose infused into the duodenum on glucose metabolism in lactating dairy cows. Measurements of milk yield, milk composition, and energy and protein supplied have been published (Rigout et al., 2003). The present paper focuses on the variations in $\mathrm{Ra}$, plasma metabolites, and hormones involved in the regulation of gluconeogenesis and in the partitioning of glucose and AA for the different metabolic functions.

\section{MATERIALS AND METHODS}

\section{Treatments and Experimental Design}

The 5 treatments consisted of a basal diet composed of grass silage and concentrate plus 5 infusions: a VFA mixture infused into the rumen (control), two doses of glucose infused into the duodenum, and two doses of C3 infused into the rumen. The combinations of diet plus infusions were formulated to provide $100 \%$ of energy requirements and $115 \%$ of protein requirements (Institut National de le Recherche Agronomique, 1989) to avoid a limiting effect of protein supply on glucose $\mathrm{Ra}$, milk, and protein yields. Treatments were also isoenergetic and isonitrogenous to compare the effect of energetic nutrients (i.e., glucose and C3), thus avoiding any protein shortage. Five cows were individually fed restricted amounts of a basal diet $(58.6 \%$ round balewrapped grass silage, $24.8 \%$ energy concentrate, $9.1 \%$ formaldehyde-treated soybean meal; DM basis) supplemented with minerals and vitamins $(200 \mathrm{~g} / \mathrm{d})$ and with L-Lys HCl (11 g/d; Ajinomoto Co. Inc., Tokyo, Japan) and DL-Met (15 g/d; Rhône-Poulenc, Commentry, France) according to the recommendations of Rulquin et al. (2001). Grass silage was chosen, and the energy concentrate was formulated, to minimize the intestinal glucose flux. The energy concentrate contained (DM basis) $20 \%$ barley, $21.5 \%$ wheat, $37 \%$ dehydrated beet pulp, $15 \%$ fine wheat bran, $2 \%$ coprah fat, $2 \%$ beet molasses, $0.5 \%$ calcium carbonate, $1 \%$ sodium bicarbonate, $1 \%$ salt. Each of the 5 isoenergetic infusions provided $3.45 \mathrm{Mcal}$ of $\mathrm{NE}_{\mathrm{L}} / \mathrm{d}$. The VFA mixture was composed of $53.9 \%$ acetic acid, $20.4 \% \mathrm{C} 3$, and $25.6 \%$ butyric acid on a molar basis. In the control treatment, this VFA mixture was continuously infused into the rumen 
at $14.6 \mathrm{~mol} / \mathrm{d}\left(3.45 \mathrm{Mcal}\right.$ of $\left.\mathrm{NE}_{\mathrm{I}} / \mathrm{d}\right)$. The 2 glucose treatments consisted, respectively, of a ruminal infusion of the VFA mixture $(7.3 \mathrm{~mol} / \mathrm{d}$ equivalent to $1.72 \mathrm{Mcal}$ of $\left.\mathrm{NE}_{\mathrm{L}} / \mathrm{d}\right)$ plus a duodenal infusion of glucose $(3.43 \mathrm{~mol} / \mathrm{d}$ equivalent to $1.72 \mathrm{Mcal}$ of $\mathrm{NE}_{\mathrm{L}} / \mathrm{d}$ ) or a duodenal infusion of only glucose $(+6.87 \mathrm{~mol} / \mathrm{d}$ equivalent to $3.45 \mathrm{Mcal}$ of $\mathrm{NE}_{\mathrm{L}} / \mathrm{d}$ ). The $2 \mathrm{C} 3$ treatments consisted of a ruminal infusion of the VFA mixture $(7.3 \mathrm{~mol} / \mathrm{d} ; 1.72 \mathrm{Mcal} / \mathrm{d})$ plus C3 (6.5 mol/d; $1.72 \mathrm{Mcal} / \mathrm{d})$, and a ruminal infusion of pure C3 (13 mol/d; $3.45 \mathrm{Mcal} / \mathrm{d})$. The higher amount of glucose infused was smaller than postrumen starch digestion in dairy cows receiving a corn silage diet (+ $12.9 \mathrm{~mol} / \mathrm{d}$ ) (Huntington, 1997). The C3 infusions increased the percentage of ruminal C3 from $17.1 \%$ for the control treatment to $25.5 \%$ (Rigout et al., 2003). The ruminal C3 percentage was slightly higher than the percentages currently observed with grass silagebased diets, but the objective of the present experiment was to describe the laws of response to increasing ruminal C3 percentages and to increasing duodenal glucose independently of the roughage used. In addition, such ruminal C3 percentage diets (25.4 and $25.9 \%$ ) were already observed with alfalfa silage diets (Allen and Grant, 2000). For further details on diets and infusions see Rigout et al. (2003).

The experiment was conducted according to a $5 \times 5$ Latin square design over 14 -d periods ( $9 \mathrm{~d}$ of transition and adaptation and $5 \mathrm{~d}$ of measurements).

\section{Cows, Feed Distribution, and Milking}

Five Holstein cows ( $613 \pm 62 \mathrm{~kg}$ of BW; $53 \pm 12$ DIM; $32 \pm 4 \mathrm{~kg} / \mathrm{d}$ of milk yield) fitted with a rumen cannula and a T-shaped duodenal cannula were used. Grass silage was fed 3 times/d (25\% at 0700 h, $25 \%$ at 1300 $\mathrm{h}$, and $50 \%$ at $1900 \mathrm{~h}$ ), and concentrate was fed 8 times/ $\mathrm{d}$ in equal portions (every $3 \mathrm{~h}$ beginning at $0700 \mathrm{~h}$ ). Access to feed was limited to $1 \mathrm{~h}$ every $3 \mathrm{~h}$ beginning at $0700 \mathrm{~h}$. With such a pattern of feed distribution, plasma glucose concentration remained stable, as did plasma concentrations of most blood metabolites (AA, acetate, BHBA, NEFA, urea) and hematocrit (Rulquin, 1981). Cows were milked twice daily at 0630 and $1800 \mathrm{~h}$.

The surgical preparation was reviewed and approved by the animal care committee of the French Ministry of Agriculture. Cows were fitted with two provisional silicone catheters (length, $21 \mathrm{~cm}$; i.d., $1.02 \mathrm{~mm}$; o.d., $2.16 \mathrm{~mm}$; Silclear Tubing, Degania, Israel) inserted into the 2 jugular veins for tracer infusions and blood sampling during the measurement of Ra. Catheter maintenance was as described by Rigout et al. (2002b).

\section{Measurements and Sampling}

The effect of treatments on Ra was measured on d 10 or 11 between 1315 and 1530 h. Two $98.0 \%$ pure solutions of $\left[6,6-{ }^{2} \mathrm{H}_{2}\right]$ glucose (Cambridge Isotope Laboratories, Andover, MA) were prepared with sterile saline for the priming dose injection and infusion and were sterilized by filtration through a $0.22-\mu \mathrm{m}$ sterile disk filter (Millipore, Saint-Quentin en Yvelines, France). The first solution (77.1 $\pm 0.8 \mathrm{~g} / \mathrm{L})$ was used for the priming dose injected through one jugular vein (35 $\mathrm{mL} ; 2.7 \mathrm{~g})$. The second solution $(54.9 \pm 0.8 \mathrm{~g} / \mathrm{L})$ was then continuously infused at a constant rate of $1.3 \mathrm{~mL} /$ min for 120 min with a syringe pump (Harvard apparatus, Les Ulis, France). To control for blood glucose coefficients of variation that were $<5 \%, 1 \mathrm{~mL}$ of blood was taken every $10 \mathrm{~min}$ (from $-20 \mathrm{~min}$ before the beginning to $80 \mathrm{~min}$ ) from the other jugular vein catheter to perform a rapid measurement of blood glucose concentration using a glucometer (LifeScan One touch; Johnson \& Johnson Company, Milpitas, CA). In addition, blood samples were collected with syringes (S-Monovette, 7.5 $\mathrm{mL}$; Sarstedt, Nümbrecht, Germany) containing heparin $(12$ to $30 \mathrm{IU} / \mathrm{mL})$ at 15 and $10 \mathrm{~min}$ before injection of $\left[6,6-{ }^{2} \mathrm{H}_{2}\right]$ glucose solution to measure the natural abundance and during the plateau period, at 80,90 , 100 , and $110 \mathrm{~min}$ after injection. Blood was centrifuged at $2500 \times \mathrm{g}$ for $10 \mathrm{~min}$ at $4^{\circ} \mathrm{C}$. Plasma samples for glucose assays were stored at $-20^{\circ} \mathrm{C}$. Plasma samples taken to measure $\left[6,6^{2} \mathrm{H}_{2}\right]$ glucose enrichments were deproteinized with an equal volume of $1.2 \mathrm{M}$ perchloric acid and filtrated before being stored at $-20^{\circ} \mathrm{C}$.

Jugular blood was sampled on d 13 of each period at $0.5,2.5,4.5,6.5,8.5$, and $10.5 \mathrm{~h}$ after morning milking. Syringes containing heparin (S-Monovette, $7.5 \mathrm{ml}$; Sarstedt) were used for AA, lactate, and urea determinations. Samples for insulin, growth hormone $(\mathbf{G H})$, and IGF-I determinations were collected with syringes containing 1.2 to $2 \mathrm{mg} / \mathrm{mL}$ of $\mathrm{K}_{2}$-EDTA (S-Monovette, 7.5 $\mathrm{ml}$; Sarstedt). Syringes containing $\mathrm{K}_{2}$-EDTA (2.6 mL) and $260 \mu \mathrm{L}(2600 \mathrm{KIU})$ of the protease inhibitor aprotinine (Antagosan; Hoechst Marion Roussel Gmbh, Marbourg, Germany) were used to collect blood for determination of glucagon concentrations. Blood samples were kept on ice and centrifuged at $2500 \times g$ for $10 \mathrm{~min}$ at $4^{\circ} \mathrm{C}$ before storage at $-20^{\circ} \mathrm{C}$.

Samples taken for lactate and AA analyses were deproteinized with $50 \% \mathrm{vol} / \mathrm{vol}$ of $0.6 \mathrm{M}$ perchloric acid and filtrated with $50 \%$ (vol/vol) sulfosalicylic acid.

On d 13 of each period, $100 \mathrm{~mL}$ of milk were taken from each cow at the morning milking. Milk samples were stored at $-20^{\circ} \mathrm{C}$ for chemical analyses in the laboratory. Milk was analyzed for glucose concentration in milk according to Rigout et al. (2002b).

\section{Chemical Analyses}

Samples for lactate, urea, and AA were pooled per cow per period before analyses. Glucose, lactate, and 
Table 1. Effect of infusions of glucogenic materials on glucose metabolism.

\begin{tabular}{|c|c|c|c|c|c|c|c|c|c|c|}
\hline \multirow[b]{3}{*}{ Treatment } & \multirow[b]{3}{*}{ Control } & \multicolumn{2}{|c|}{ Glucose } & \multicolumn{2}{|c|}{$\mathrm{C} 3^{1}$} & \multirow[b]{3}{*}{$\mathrm{SEM}^{3}$} & \multirow{2}{*}{\multicolumn{4}{|c|}{ Contrast $^{2}$}} \\
\hline & & $1.72 \mathrm{Mcal}$ & $3.45 \mathrm{Mcal}$ & 172 Mcal & $3.45 \mathrm{Mcal}$ & & & & & \\
\hline & & $\mathrm{NE}_{\mathrm{L}} / \mathrm{d}$ & $\mathrm{NE}_{\mathrm{L}} / \mathrm{d}$ & $\mathrm{NE}_{\mathrm{L}} / \mathrm{d}$ & $\mathrm{NE}_{\mathrm{L}} / \mathrm{d}$ & & $\mathrm{A}$ & $\mathrm{B}$ & $\mathrm{C}$ & $\mathrm{D}$ \\
\hline \multicolumn{11}{|l|}{ Plasma concentration } \\
\hline Glucose ${ }^{4} \mathrm{mmol} / \mathrm{L}$ & 3.70 & 3.58 & 3.97 & 3.63 & 3.72 & 0.068 & $\mathrm{NS}^{8}$ & NS & $* *$ & * \\
\hline Insulin, $\mu \mathrm{g} / \mathrm{L}$ & 0.97 & 1.08 & 1.12 & 1.01 & 0.96 & 0.057 & NS & $\dagger$ & NS & NS \\
\hline Glucagon, ng/L & 81.9 & 75.5 & 79.1 & 75.4 & 81.0 & 2.55 & NS & NS & NS & NS \\
\hline $\mathrm{GH}^{5}, \mu \mathrm{g} / \mathrm{L}$ & 8.48 & 6.70 & 6.30 & 6.94 & 5.05 & 0.794 & * & NS & NS & NS \\
\hline $\mathrm{Ra},{ }^{6} \mathrm{~mol} / \mathrm{d}$ & 13.0 & 13.3 & 16.7 & 13.9 & 13.5 & 0.84 & NS & NS & $\dagger$ & * \\
\hline Milk yield, $\mathrm{kg} / \mathrm{d}$ & 25.2 & 26.3 & 26.8 & 26.0 & 25.9 & 0.50 & $\dagger$ & NS & NS & NS \\
\hline Glucose in milk, mmol/L & 0.48 & 0.52 & 0.58 & 0.50 & 0.53 & 0.021 & $\dagger$ & NS & $\dagger$ & NS \\
\hline Lactose: $\mathrm{Ra}^{7}$ & 0.53 & 0.57 & 0.45 & 0.53 & 0.57 & 0.078 & NS & NS & NS & $*$ \\
\hline
\end{tabular}

${ }^{1} \mathrm{C} 3$ = propionic acid.

${ }^{2}$ Contrast A: control vs. other (effect of glucogenic materials such as duodenal glucose or ruminal propionate); Contrast B: duodenal glucose vs. ruminal propionic acid; Contrast C: effect of level of glucogenic materials; and Contrast D: interaction between duodenal glucose and ruminal propionic acid.

${ }^{3}$ For the treatment of $1.72 \mathrm{Mcal} \mathrm{NE} / \mathrm{d}$ of infused propionic acid (one missing cell), the $\mathrm{SEM}$ is $1.19 \times \mathrm{SEM}$ presented in the table.

${ }^{4}$ Plasma glucose was determined during the measurement of glucose appearance rate (Ra).

${ }^{5} \mathrm{GH}=$ Growth hormone.

${ }^{6}$ The Ra was measured with $\left[6,6{ }^{2} \mathrm{H}_{2}\right]$ glucose infusion.

${ }^{7}$ Ratio calculated with lactose and $\mathrm{Ra}$ expressed in $\mathrm{g} / \mathrm{d}$.

${ }^{8} P>0.10$.

$\dagger P \leq 0.1$.

$* P \leq 0.05$.

$* * P \leq 0.01$.

urea were measured on a multiparameter analyzer (KONE Instruments Corporation, Espoo, Finland) using a KONE kit for glucose, a Bio-Mérieux kit (BioMérieux S.A., Marcy-l'Etoile, France) for L-lactate, and a Wako kit (Oxoid S.A., Dardilly, France) for NEFA determinations. Plasma-free AA concentrations were determined according to Hurtaud et al. (2000). Insulin, glucagon, GH, and IGF-I were analyzed by radioimmunoassay as described by Rigout et al. (2002b).

Preparation of samples before GLC/mass spectrometry analysis to determine $\left[6,6-{ }^{2} \mathrm{H}_{2}\right]$ glucose enrichments was described by Rigout et al. (2002b). Derivatization was made with butaneboronic acid followed by addition of acetic anhydride. Each molar ratio (the ratio of $[6,6-$ ${ }^{2} \mathrm{H}_{2}$ ]glucose to glucose; i.e., the ratio of $\mathrm{m} / \mathrm{z}=299$ to $\mathrm{m} /$ $\mathrm{z}=297$ ) was determined in triplicate by GLC/mass spectrometry in electron impact ionization mode (GC 8060 chromatograph coupled to a VG Platform II; Fisons Instruments, Altrincham, England). The glucose enrichment expressed in molecular percentage excess was then calculated (Rigout et al., 2002b). A control plasma at $3.73 \mathrm{~mol} \%$ excess was introduced in each batch of analysis; the coefficient of variation between batches was $1.63 \%$.

\section{Calculations and Statistical Analyses}

Estimation of $\mathrm{Ra}$ (g/min), equal to hepatic plus renal production of glucose plus intestinal absorption of glucose, was determined by the steady-state equation:

$$
\mathrm{Ra}=\mathrm{F} \times(\mathrm{IEinf} / \mathrm{Iep}-1)
$$

where $\mathrm{F}$ is the $\left[6,6-{ }^{2} \mathrm{H}_{2}\right]$ glucose infusion rate $(\mathrm{mL} / \mathrm{min})$, IEinf is the isotopic enrichment of the infusate (i.e., 98 mol\% excess), and IEp (also in mol\% excess) is the plasma $\left[6,6-{ }^{2} \mathrm{H}_{2}\right]$ glucose enrichment.

Mean values of each cow per period were used in statistical analyses. Each parameter was analyzed using the general linear model procedure of SAS (1990) according to the following statistical model: Yijk $=\mu+$ $\mathrm{Ci}+\mathrm{Pj}+\mathrm{Tk}+$ eijk where $\mathrm{C}, \mathrm{P}$, and $\mathrm{T}$ are cow, period, and treatment effects, respectively. Results were expressed as least squares means with standard errors of means because of missing values over period 4 for one cow that had mastitis. The VFA treatment was considered the control. Differences among treatments with least squares means were compared using 4 orthogonal polynomial contrasts between control (VFA), glucose dose 1 and $2\left(\mathrm{G}_{1}\right.$ and $\left.\mathrm{G}_{2}\right)$, and C3 dose 1 and 
Table 2. Effect of infusions of glucogenic materials on plasma AA concentrations.

\begin{tabular}{|c|c|c|c|c|c|c|c|c|c|c|}
\hline \multirow[b]{3}{*}{ Treatment } & \multirow[b]{3}{*}{ Control } & \multicolumn{2}{|c|}{ Glucose } & \multicolumn{2}{|c|}{$\mathrm{C} 3^{1}$} & \multirow[b]{3}{*}{$\mathrm{SEM}^{3}$} & \multirow{2}{*}{\multicolumn{4}{|c|}{ Contrast $^{2}$}} \\
\hline & & \multirow{2}{*}{$\begin{array}{l}1.72 \mathrm{Mcal} \\
\mathrm{NE}_{\mathrm{L}} / \mathrm{d}\end{array}$} & \multirow{2}{*}{$\begin{array}{l}3.45 \mathrm{Mcal} \\
\mathrm{NE}_{\mathrm{L}} / \mathrm{d}\end{array}$} & \multirow{2}{*}{$\begin{array}{l}1.72 \mathrm{Mcal} \\
\mathrm{NE}_{\mathrm{L}} / \mathrm{d}\end{array}$} & \multirow{2}{*}{$\begin{array}{l}3.45 \mathrm{Mcal} \\
\mathrm{NE}_{\mathrm{L}} / \mathrm{d}\end{array}$} & & & & & \\
\hline & & & & & & & A & B & $\mathrm{C}$ & $\mathrm{D}$ \\
\hline & & & $(\mu \mathrm{mol} / \mathrm{L})$ & & & & & & & \\
\hline Lys & 83.5 & 86.2 & 72.5 & 73.2 & 82.8 & 5.61 & $\mathrm{NS}^{4}$ & NS & NS & $\dagger$ \\
\hline His & 42.5 & 38.1 & 32.3 & 33.8 & 48.3 & 4.70 & NS & NS & NS & $\dagger$ \\
\hline Arg & 79.2 & 80.3 & 80.0 & 67.0 & 82.0 & 7.43 & NS & NS & NS & NS \\
\hline Thr & 72.0 & 92.1 & 83.6 & 79.9 & 101.2 & 6.18 & * & NS & NS & $*$ \\
\hline Val & 215.2 & 178.0 & 138.3 & 175.7 & 186.3 & 12.09 & $* *$ & $\dagger$ & NS & $\dagger$ \\
\hline Met & 36.4 & 37.1 & 39.1 & 34.4 & 39.3 & 2.07 & NS & NS & NS & NS \\
\hline Ile & 127.6 & 97.9 & 78.4 & 100.7 & 99.1 & 5.34 & $* *$ & $*$ & $\dagger$ & NS \\
\hline Leu & 105.1 & 74.3 & 62.1 & 73.9 & 85.4 & 8.25 & $* *$ & NS & NS & NS \\
\hline Phe & 43.6 & 45.4 & 48.4 & 44.2 & 49.0 & 4.00 & NS & NS & NS & NS \\
\hline Asp + Asn & 63.5 & 79.9 & 75.9 & 64.0 & 81.1 & 3.94 & * & NS & NS & $*$ \\
\hline Ser & 73.8 & 98.3 & 98.0 & 84.1 & 95.2 & 3.89 & $* *$ & $*$ & NS & NS \\
\hline Glu + Gln & 202.9 & 257.4 & 271.6 & 223.8 & 242.0 & 11.84 & $* *$ & $\dagger$ & NS & NS \\
\hline Gly & 305.9 & 357.7 & 349.7 & 291.7 & 311.8 & 8.30 & $*$ & $* *$ & NS & NS \\
\hline Ala & 177.5 & 200.1 & 188.4 & 172.6 & 209.0 & 9.67 & NS & NS & NS & $*$ \\
\hline Tyr & 46.2 & 46.2 & 52.3 & 45.9 & 52.7 & 4.37 & NS & NS & NS & NS \\
\hline Cys & 29.8 & 27.4 & 24.1 & 27.4 & 27.4 & 1.10 & $*$ & NS & NS & NS \\
\hline Orn & 60.0 & 59.3 & 49.6 & 52.5 & 58.6 & 2.70 & NS & NS & NS & $*$ \\
\hline Cit & 66.7 & 72.4 & 76.2 & 66.8 & 70.0 & 2.60 & NS & $*$ & NS & NS \\
\hline Tau & 41.6 & 43.8 & 45.8 & 42.1 & 50.6 & 2.18 & NS & NS & $*$ & NS \\
\hline Urea & 2657 & 2631 & 2834 & 2919 & 2641 & 254.5 & NS & NS & NS & NS \\
\hline $\mathrm{EAA}^{5}$ & 805 & 730 & 635 & 682 & 774 & 51.0 & $\dagger$ & NS & NS & $\dagger$ \\
\hline NEAA $^{5}$ & 900 & 1067 & 1060 & 909 & 1019 & 29.9 & $* *$ & $* *$ & NS & $\dagger$ \\
\hline $\mathrm{TAA}^{5}$ & 1873 & 1972 & 1866 & 1753 & 1972 & 76.4 & NS & NS & NS & $\dagger$ \\
\hline $\mathrm{BCAA}^{5}$ & 448 & 350 & 279 & 350 & 371 & 25.1 & $* *$ & $\dagger$ & NS & $\dagger$ \\
\hline Gluco. $\mathrm{AA}^{5}$ & 1021 & 1185 & 1172 & 1010 & 1149 & 37.7 & $*$ & $*$ & NS & $\dagger$ \\
\hline EAA:NEAA & 88.9 & 68.5 & 60.1 & 75.0 & 75.4 & 3.72 & $* *$ & * & NS & NS \\
\hline EAA:TAA & 42.7 & 37.0 & 33.9 & 38.9 & 38.9 & 1.22 & $* *$ & * & NS & NS \\
\hline
\end{tabular}

${ }^{1} \mathrm{C} 3$ = Propionic acid.

${ }^{2}$ Contrast A: control vs. other (effect of glucogenic materials such as duodenal glucose or ruminal propionate); Contrast B: duodenal glucose vs. ruminal propionic acid; Contrast C: effect of level of glucogenic materials; and Contrast D: interaction between duodenal glucose and ruminal propionic acid.

${ }^{3}$ For the treatment of $1.72 \mathrm{Mcal} \mathrm{NE} / \mathrm{d}$ of infused propionic acid (one missing cell), the $\mathrm{SEM}$ is $1.19 \times$ SEM presented in the table.

${ }^{4} P>0.10$.

${ }^{5} \mathrm{EAA}=$ Essential AA (Lys, His, Arg, Thr, Val, Met, Ile, Leu, and Phe), NEAA = non-essential AA (Asp, Asn, Ser, Glu, Gln, Gly, Ala, Tyr, and Cys); TAA = Total AA (EAA + NEAA); BCAA = branched-chain AA (Val, Leu, and Ile), and Gluco. AA = glucogenic AA = NEAA + His + Arg.

$\dagger P \leq 0.1$.

$* P \leq 0.05$.

$* * P \leq 0.01$.

dose $2\left(\mathrm{C}_{1}\right.$ and $\left.\mathrm{C} 3_{2}\right)$. Contrast $\mathrm{A}$ was used to test the effect of glucogenic materials such as duodenal glucose or ruminal C3 (control vs. other: $-4 \mathrm{VFA}, 1 \mathrm{G}_{1}, 1 \mathrm{G}_{2}, 1 \mathrm{C} 3_{1}$, and $1 \mathrm{C}_{2}$ ). Contrast $\mathrm{B}$ was used to test duodenal glucose vs. ruminal propionic acid $\left(-1 \mathrm{G}_{1},-1 \mathrm{G}_{2}, 1 \mathrm{C} 3_{1}\right.$, and $\left.1 \mathrm{C} 3_{2}\right)$. Contrast $\mathrm{C}$ was used to test the effect of level of glucogenic materials $\left(1 \mathrm{G}_{1},-1 \mathrm{G}_{2}, 1 \mathrm{C} 3_{1}\right.$, and $\left.-1 \mathrm{C}_{2}\right)$. Contrast $\mathrm{D}$ was used to test the interaction between duodenal glucose and ruminal propionic $\left(1 \mathrm{G}_{1},-1 \mathrm{G}_{2},-1 \mathrm{C} 3_{1}\right.$, and $1 \mathrm{C} 3_{2}$ ). The significance threshold was set at $P \leq 0.05$, and the tendency threshold was set at $P \leq 0.10$.

\section{RESULTS}

Plasma glucose concentration was not modified by infusions of glucogenic materials relative to control (Table 1; Contrast A). Similar values of plasma glucose concentrations were observed with duodenal infusions of glucose and ruminal infusions of C3 (Contrast B), but the concentration was significantly increased with the level of infusions of both glucogenic materials and the interaction between glucose and C3 was significant (Contrast D). During the intravenous infusion of $[6,6-$ ${ }^{2} \mathrm{H}_{2}$ ]glucose, plasma glucose concentrations and enrich- 
ments were maintained at a steady state regardless of the treatment performed. The coefficients of variation for concentrations and enrichments of plasma glucose were $<5 \%$. They ranged from 1.54 to $4.65 \%$ and 0.4 to $4.21 \%$, respectively. The steady-state model was then used to calculate Ra. Glucose Ra was not significantly modified by the infusions of glucogenic materials compared with control VFA. However, glucose Ra tended to increase with the level of infusions of both glucose and C3 (Contrast C). In addition, Ra was higher with the high dose of glucose infused, leading to a significant interaction (Contrast D).

Plasma insulin concentration remained unchanged in response to infusions of both glucogenic materials and the control treatment but tended to be higher when comparing duodenal glucose and ruminal C3 (Contrast B: $P<0.1$ ). Plasma glucagon concentrations were similar across all treatments. Plasma IGF-I concentration increased, whereas plasma GH decreased, with infusions of both glucose and C3 compared with the control treatment (Contrast A). However, the increased plasma IGF-I concentration was significantly greater in response to glucose treatments than in response to $\mathrm{C} 3$ treatments (Contrast B). In addition, plasma IGF-I concentration increased with the level of infusions of both glucogenic materials (Contrast C).

Plasma lactate concentration remained unchanged with both glucogenic materials compared with the control. Plasma lactate concentration tended to be lower in response to duodenal glucose treatments compared with ruminal C3 treatments, and the interaction tended to be significant (Contrast $\mathrm{D}$ ) because it decreased with the level of duodenal glucose and increased between the first and the second doses of ruminal C3.

Among EAA, both treatments significantly decreased the plasma concentrations of the three branched-chain AA (BCAA) and Thr compared with the control treatment (Table 2; Contrast A). However, glucose treatments tended to significantly decrease BCAA compared with C3 treatments (Contrast B). The interaction tended to be significant (Contrast D) because BCAA decreased when the level of duodenal glucose increased, which was not the case with ruminal C3 infusions. Both glucogenic materials significantly decreased (Contrast A) the ratio of EAA to non essential AA (NEAA), but the decrease was significantly more important with glucose treatments compared with $\mathrm{C} 3$ treatments (Contrast B). Among NEAA, the sum of glucogenic AA concentrations increased in response to both glucose and C3 treatments (Contrast A), but the increase was significantly higher with glucose treatments compared with C3 treatments (Contrast B). Among glucogenic AA, considered to be highly oxidized, the sum of Asp + Asn and Ser, were significantly increased in response to both glucose and C3 treatments compared with the control treatment (Contrast A). The sum of Glu + Gln and Gly also increased with both treatments. However, the increases in some glucogenic AA (Ser and Gly) were significantly higher or tended to be higher (Glu + Gln) with glucose treatments than with $\mathrm{C} 3$ treatments. Urea remained unchanged during treatments. The interaction between glucose and C3 treatments was significant for Thr, Asp + Asn, Ala, and Orn or tended to be significant for Lys, His, Val, EAA, NEAA, total AA (TAA), BCAA, and glucogenic AA because the concentrations decreased with increasing levels of duodenal glucose and increased with increasing levels of ruminal C3.

It has been previously reported (Rigout et al., 2003) that milk yield tended to increase in response to both glucose and C3 treatments compared with the control treatment (Table 1; Contrast A; $P=0.09$ ). No significant differences were found between glucose and C3 treatments. Glucose concentration in milk also tended to increase in response to both glucose and C3 treatments (Table 1; Contrast A) and tended to increase with the level of infusion of glucogenic materials (Contrast C) with no difference between duodenal glucose and ruminal C3 treatments. The ratio of lactose production to $\mathrm{Ra}$ was decreased with the high dose of glucose treatments leading to a significant interaction between glucose and C3 treatments (Contrast D).

\section{DISCUSSION}

\section{A Low Precision in Ra Measurement}

In the present experiment, the root mean squares error (RMSE) $(1.88 \mathrm{~mol} / \mathrm{d})$ was higher than the RMSE $(1.06 \mathrm{~mol} / \mathrm{d} ; 0.86 \mathrm{~mol} / \mathrm{d})$ obtained in other experiments of nutrient infusions into the digestive tract using the same procedure to measure $\mathrm{Ra}$ (Rigout et al. 2002; unpublished data). The statistical analysis of the residual errors showed that this high RMSE was mainly due to Ra data obtained with one cow (Cow 5) when receiving the high dose of C3. If these data were removed, the RMSE of Ra would be $1.42 \mathrm{~mol} / \mathrm{d}$. The Ra of the $2 \mathrm{C} 3$ treatments would be 13.7 and 14.7, respectively. If the data from Cow 5 receiving the high dose of C3 were removed from the data set of statistical analysis, both glucose and C3 treatments significantly increased $\mathrm{Ra}$ compared with the control treatment (Contrast A; $P<$ 0.05) and $\mathrm{Ra}$ increased with the level of infusions of glucogenic materials (Contrast C; $P<0.01$ ) with no difference between glucose and C3 (Contrasts B and C; NS). However, there is no reason to remove these data. First, this Ra data seemed not be explained by an error of enrichment measurements. Second, no physiological trouble was shown. Third, Cow 5 exhibited similar values in comparison with other cows for all the other 

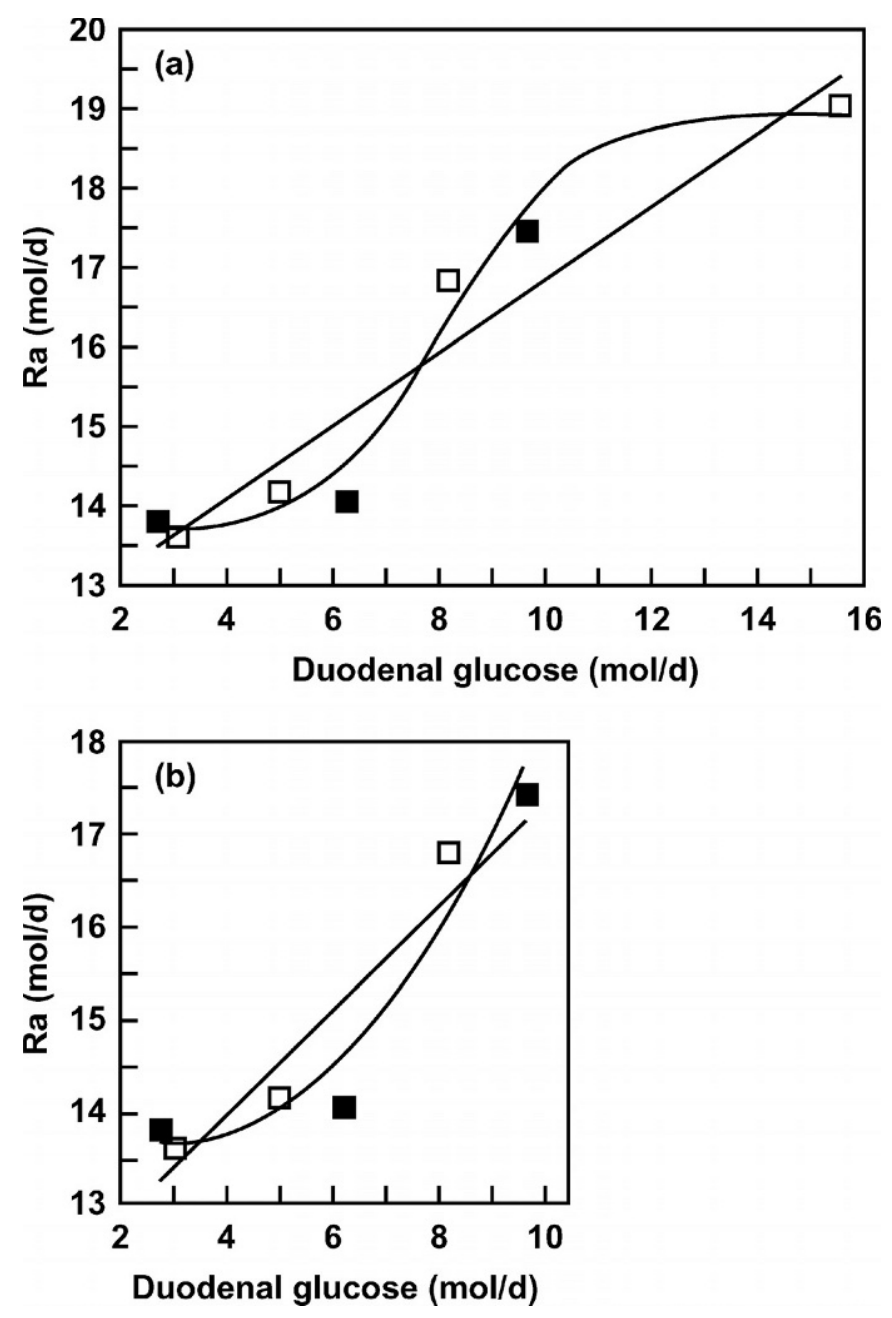

Figure 1. Effect of duodenal glucose on glucose appearance rate (Ra) in the present experiment ( $\mathbf{\square}$ ) and in the experiment of Rigout et al. (2002b) ( $\square$ ). Duodenal glucose corresponds to the sum of infused glucose plus the intestinal glucose provided by the diet (Rigout et al., 2003). In (a), all values are included. Regression equations are as follows: for the sigmoidal curve, $\mathrm{Ra}(\mathrm{mol} / \mathrm{d})=13.6+5.32 /[1+$ $\exp (6.9-0.85 \times \mathrm{Glc})]\left(\mathrm{n}=7 ; \mathrm{R}^{2}=0.98 ; \mathrm{SE}=0.46 \mathrm{~mol} / \mathrm{d} ; P<0.01\right) ;$ for the linear curve, $\mathrm{Ra}(\mathrm{mol} / \mathrm{d})=12.2+0.46 \times \mathrm{Glc}\left(\mathrm{n}=7 ; \mathrm{R}^{2}=0.90\right.$; $\mathrm{SE}=0.74 \mathrm{~mol} / \mathrm{d} ; P<0.01)$. In (b), the highest value of duodenal glucose $(15.6 \mathrm{~mol} / \mathrm{d})$ was excluded. Regression equations are as follows: for the quadratic curve, $\mathrm{Ra}(\mathrm{mol} / \mathrm{d})=14.6-0.58 \times \mathrm{Glc}+0.09 \times \mathrm{Glc}^{2}(\mathrm{n}=$ 6; $\left.\mathrm{R}^{2}=0.93 ; \mathrm{SE}=0.56 \mathrm{~kg} / \mathrm{d} ; P<0.05\right)$; for the linear curve, $\mathrm{Ra}(\mathrm{mol} /$ d) $=11.72+0.56 \times$ Glc $\left(\mathrm{n}=6 ; \mathrm{R}^{2}=0.84 ; \mathrm{SE}=0.75 \mathrm{~kg} / \mathrm{d} ; P<0.01\right)$.

parameters measured during the high dose of ruminal C3 infusions (Rigout et al., 2003). Nevertheless, the effect of rumen C3 on Ra should be interpreted with caution.

\section{Duodenal Glucose Increase in Ra May Follow a Sigmoidal Curve}

Increasing amounts of glucose infused into the duodenum increased Ra (Figure 1) in the present experiment as in the previous experiment (Rigout et al., 2002b). The sum of intestinal glucose provided by the diets and the infusions were calculated for each glucose treatment in both experiments (Rigout et al., 2003). Using these experiments, Ra seemed to increase following a sigmoidal curve in response to increasing total amounts of duodenal glucose (Figure 1a). This result differed from steers whose net portal glucose absorption increased linearly in response to increasing amounts of glucose infused between 0 and $8 \mathrm{~mol} / \mathrm{d}$ (Kreikemeier et al., 1991). If our data were fitted to a linear regression, the increase in Ra with total duodenal glucose would correspond to a slope of $+0.46 \mathrm{~mol} / \mathrm{mol}$ of glucose. This value was lower than the slope of net portal glucose absorption $(+0.62 \mathrm{~mol} / \mathrm{mol})$ obtained with similar amounts (44 to $55.5 \mathrm{mmol} / \mathrm{kg}^{0.75}$ per d) infused into steers (Kreikemeier et al., 1991). This difference may be explained by a reduction of endogenous glucose production. In our two experiments, better results were obtained when mean data were fitted according to the sigmoidal curve $\left(R^{2}=0.98 ; \mathrm{SE}=0.46 \mathrm{~mol} / \mathrm{d}\right)$ than to a linear regression $\left(\mathrm{R}^{2}=0.90 ; \mathrm{SE}=0.74 \mathrm{~mol} / \mathrm{d}\right)$. The robustness of the beginning of the sigmoidal equation is a weak point because of the high SEM obtained in the present experiment. However, the high SEM was not due to glucose treatment, and the SEM was lower in the other experiment $(+0.43 \mathrm{~mol} / \mathrm{d})$. In addition, to analyze the beginning of curve, the highest value (15.6 $\mathrm{mol} / \mathrm{d}$ of total duodenal glucose) was excluded, and only $2.5 \mathrm{~mol} / \mathrm{d}$ to $11 \mathrm{~mol} / \mathrm{d}$ of total glucose were considered (Figure 1b). In this case, the data were still better fitted using a quadratic regression $\left(\mathrm{R}^{2}=0.93 ; \mathrm{SE}=0.56 \mathrm{~mol} /\right.$ d) than a linear regression $\left(\mathrm{R}^{2}=0.84 ; \mathrm{SE}=0.74 \mathrm{~mol} / \mathrm{d}\right)$.

The hypothesis of a very low increase in Ra between $2.5 \mathrm{~mol} / \mathrm{d}$ to $4.5 \mathrm{~mol} / \mathrm{d}$ of duodenal glucose ( 0 to $2.5 \mathrm{~mol} /$ d of glucose infused) as suggested in Figure 1 may not be linked to a reduction of endogenous glucose production because it is unlikely that endogenous production from substrates other than glucose was decreased with the low level of glucose infusion (Rigout et al., 2002b). This hypothesis rather suggests that glucose was directly metabolized by the intestinal tissues when absorbed with no increased glucose availability in arterial blood. In this regard, glucose infused at these doses ( 0 to 2.5 $\mathrm{mol} / \mathrm{d}$ ) was completely absorbed by the small intestine in steers and lactating cows (Kreikemeier et al., 1991; Huntington, 1997), and in lactating dairy cows, the viscera were estimated to use $5.9 \mathrm{~mol} / \mathrm{d}$ of glucose (Huntington, 1997). To confirm this hypothesis, further works are needed to analyze luminal glucose utilization and intestinal glucose uptake from arterial blood glucose in lactating cows (Piccioli Capelli et al., 1997). An increased amount of glucose metabolized in the intestinal tissue could spare the use of other substrates for 
gluconeogenesis and explain the increased jugular plasma concentration of glucogenic AA with duodenal glucose treatments. However, to our knowledge, liver net balances of AA were never measured in lactating ruminants receiving post-ruminal glucose infusions.

In Figure 1, at 5.6 to $10 \mathrm{~mol} / \mathrm{d}$ of duodenal glucose (from 3 to $8 \mathrm{~mol} / \mathrm{d}$ of glucose infused), the small intestine did not further increase the amount of glucose directly utilized when absorbed. In addition, endogenous glucose release was not reduced because the slope of $\mathrm{Ra}$ increase was about 0.9 . A similarly substantial recovery of infused glucose in the portal vein was reported in steers infused with $2.66 \mathrm{~mol} / \mathrm{d}$ of glucose (Kreikemeier et al., 1991). In sheep and steers, the recovery of infused glucose varied on average between 29 and $84 \%$ (Piccioli Capelli et al., 1997).

At $>12.2 \mathrm{~mol} / \mathrm{d}$ of duodenal glucose in Fig. 1, Ra tended to reach the asymptotic line, suggesting that hepatic gluconeogenesis was decreased as observed in lactating cows receiving intravenous infusion of glucose (Baird et al., 1980). Below $16.6 \mathrm{~mol} / \mathrm{d}$, maximal intestinal capacity to absorb glucose was probably not reached in lactating dairy cows according to Huntington (1997).

\section{At the High Dose, Duodenal Glucose Increased Ra, but the Effective Isoenergetic Supply of C3 on Ra Remained Unclear}

Because of the high RMSE obtained for $\mathrm{Ra}$ in the present experiment, only the high dose of glucose infused into the duodenum increased $(16.7 \mathrm{~mol} / \mathrm{d})$ more $\mathrm{Ra}$ than all the other treatments ( 13.0 to $13.9 \mathrm{~mol} / \mathrm{d}$ ), leading to a significant interaction between glucose and C3. The absence of any clear effect of the high dose of C3 infused into the rumen on Ra may be surprising. The absence of a significant increase in hepatic glucose net fluxes has already been observed in lactating cows receiving C3 infusions in the mesenteric vein (Lomax et al., 1979; Baird et al., 1980; Casse et al., 1994) and in lambs receiving $\mathrm{C} 3$ infusions into the rumen at doses similar to those in the present experiment (Majdoub et al., 2003). However, in the present experiment, if the value from Cow 5 receiving the high dose of C3 was removed from the data set, Ra would increase with $\mathrm{C} 3$ infused at the high dose $(+14.8 \mathrm{~mol} / \mathrm{d})$, and the Ra would significantly increase in response to both glucogenic materials compared with the control treatment (Contrast A; $P<0.05$ ) and in response to the level of infusions (Contrast $\mathrm{C} ; P<0.05$ ).

Rate of appearance response to $\mathrm{C} 3$ administered in the rumen (infused or given as salt) was only measured in non-lactating ruminants in few experiments. Figure 2 shows the increase in Ra caused by $\mathrm{C} 3$ given when both $\mathrm{C} 3$ and $\mathrm{Ra}$ are expressed in $\mathrm{mmol} / \mathrm{kg}^{0.75}$ per day

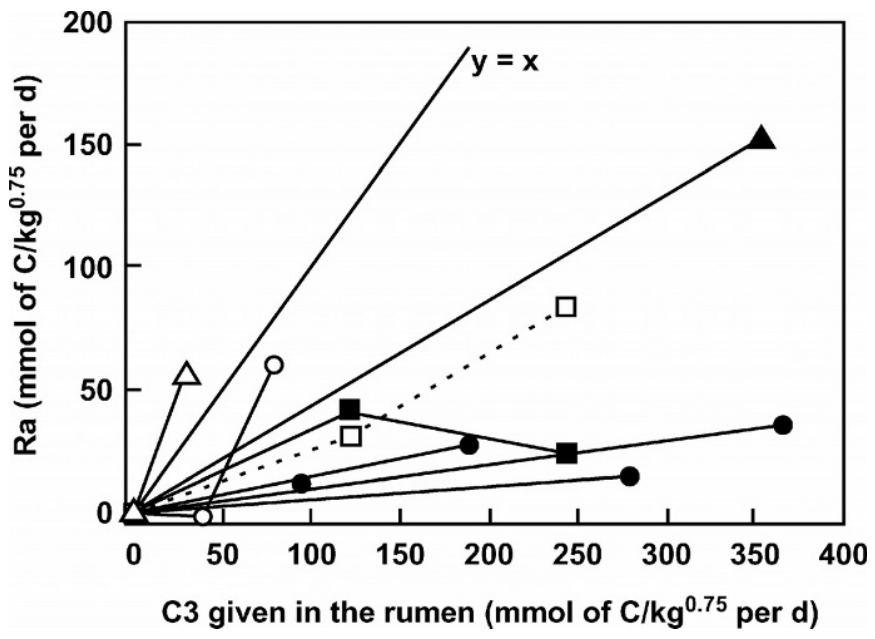

Figure 2. Increase in glucose appearance rate (Ra) as a function of propionic acid (C3) given into the rumen. Both Ra and C3 are expressed in $\mathrm{mmol}$ of $\mathrm{C} / \mathrm{kg}^{0.75}$ per day in the present experiment (ם), and when cow 5 receiving the high dose of C3 was removed ( $\square$ ), in different sheep (๑; Judson and Leng, 1973) and in steers (○; Seal and Parker 1994; $\boldsymbol{\Lambda}$, Veenhuinzen et al., 1994; $\triangle$, Peiris et al., 1998).

of Carbon $(3 \times \mathrm{C} 3$ and $6 \times \mathrm{Ra}$, respectively). The increase observed with the $\mathrm{C} 3$ infusions in the present experiment (122 and $244 \mathrm{mmol}$ of Carbon $/ \mathrm{kg}^{0.75}$ per day of C3) was in the range of variation of those observed when C3 was given into the rumen (Figure 2) at similar doses (94.4 to $367.4 \mathrm{mmol}$ of $\mathrm{C} / \mathrm{kg}^{0.75}$ per d) in sheep or steers (Judson and Leng, 1973; Veenhuizen et al., 1988). Data from Peiris et al. (1998) were inconsistent because the slope should not be $>1$. With the first dose of C3 infused or if the data from Cow 5 were suppressed at the high dose of $\mathrm{C} 3$, the slope of increase obtained in the present experiment would be very close to those ( 0.42 when expressed as carbon ratio) obtained by Veenhuizen et al. (1988). It should be noted, however, that, in the present experiment, the increase in Ra with ruminal C3 should have been $>2.7 \mathrm{~mol} / \mathrm{d}$ to be significant because of the high value of SEM, which involved a conversion efficiency for ruminal C3 to glucose $>0.42$ (when expressed in carbon ratio). The significant increases in Ra with C3 infusions in the experiment of Veenhuizen et al. (1988) might be linked to the lower SEM obtained and to the increased energy supply by C3 given because Ra increased with energy supply (Wieghart et al., 1986).

The slope of Ra increase in the present experiment and in Veenhuizen et al. (1988) suggested that carbon from C3 accounted for less than one-half of carbon of glucose produced. The slopes obtained in such experiments should not be considered as an absolute increment because C3 was given in supplement to a diet that produced $\mathrm{C} 3$ into the rumen. In the present experi- 
ment, the total amount of C3 (produced and infused as VFA) in the control treatment was estimated to be 352 $\mathrm{mmol}$ of $\mathrm{C} / \mathrm{kg}^{0.75}$ per d (Rigout et al., 2003). If the 0.42 coefficient was applied, total C3 in the control treatment would only account for $3 \mathrm{~mol} / \mathrm{d}$ of Ra, which is too low. The slopes obtained in the present experiment and in Veenhuizen et al. (1988) were lower than the slope (0.76) observed in steers receiving a lower infusion rate (79.3 mmol of $\mathrm{C} / \mathrm{kg}^{0.75}$ per $\mathrm{d}$ ). In that regard, results obtained with infusions suggest that Ra response to rumen $\mathrm{C} 3$ followed a curvilinear curve.

\section{Factors Involved in the Effects of C3 and Glucose on Ra}

An extensive C3 metabolism into the rumen wall might have explained the relatively low coefficient of conversion found in the present experiment. However, mean portal recovery rates of $\mathrm{C} 3$ infused were high and varied between 75 and 100\% in steers (Seal and Parker, 1994) and in lambs (Majdoub et al., 2003) receiving similar infusion rates of $\mathrm{C} 3\left(122 \mathrm{mmol}\right.$ of $\mathrm{C} / \mathrm{kg}^{0.75}$ per $\mathrm{d}$ to $219 \mathrm{mmol}$ of $\mathrm{C} / \mathrm{kg}^{0.75}$ per d) in comparison with the present experiment. In that regard, the only hypothesis to explain the low coefficient of conversion of infused $\mathrm{C} 3$ to $\mathrm{Ra}$ is that endogenous glucose release in blood and mainly liver net flux of glucose follows a curvilinear pattern in response to increasing infusions of C3. In the liver of lactating cows (Baird et al., 1980), the ratio of glucose release to C3 uptake decreased with C3 mesenteric infusions.

Propionic acid is a potent inhibitor of the other glucogenic pathways (Demigné et al., 1991), which might have decreased gluconeogenesis from substrates other than C3. However, in the present experiment, with the concentrations of AA, lactate, and insulin observed in peripheral blood, there is no evidence of a greater reduction of net hepatic glucose flux with ruminal C3 than with duodenal glucose. Both glucose infused into the duodenum and C3 into the rumen probably reduced gluconeogenesis from AA because plasma concentrations of glucogenic AA significantly increased with both glucogenic materials. The tendency for a higher plasma lactate concentration with the high dose of ruminal C3 relative to the high dose of glucose might indicate a higher conversion of propionate to lactate in the rumen, which might favor hepatic gluconeogenesis from lactate at the high $\mathrm{C} 3$ dose. It might also indicate reduced lactate utilization for gluconeogenesis. However, in lambs receiving ruminal C3 infusion at a similar dose, hepatic net flux of glucose remained unchanged despite an increase of portal availability of lactate and an unchanged fractional extraction by the liver (Majdoub et al., 2003). In addition, in lactating dairy cows, a sub- stantial portion of the lactate assimilated by the liver is presumably not used for gluconeogenesis (Baird et al., 1983). Lastly, plasma insulin significantly increased in peripheral blood with the high dose of glucose infused into the duodenum compared with C3 infused into the rumen. The slightly increased insulin in peripheral blood with duodenal glucose is in agreement with previous studies (Lemosquet et al., 1997; Hurtaud et al., 2000; Rigout et al., 2002b). In addition, the absence of a significant increase in peripheral plasma insulin and hepatic glucose net fluxes has already been observed in lactating cows receiving $\mathrm{C} 3$ infusions in the mesenteric vein (Lomax et al., 1979; Baird et al., 1980; Casse et al., 1994) and in lambs receiving ruminal C3 infusions (Majdoub et al., 2003).

\section{Glucose Utilization in the Mammary Gland}

An increased Ra leading to increased glucose utilization by the mammary gland was the first hypothesis to explain the increased lactose production and milk yield generally observed with isoenergetic infusions of both glucose and C3 treatments (Rigout et al., 2002b, 2003). In this regard, when duodenal glucose was infused at the high dose, $\mathrm{Ra}(+16.7 \mathrm{~mol} / \mathrm{d})$ and milk yield $(+26.8$ $\mathrm{kg} / \mathrm{d}$ ) were higher than with the other treatments. Because of the higher Ra obtained at this dose, the interaction between glucose and C3 was significant. However, in the present experiment, milk yield only tended to increase $(P=0.09)$ with both glucogenic materials (Rigout et al., 2003). In that regard, it is difficult to analyze a small increase in milk response (tendency) in relation to the Ra measurement because of the high SEM obtained for $\mathrm{Ra}(+0.84 \mathrm{~mol} / \mathrm{d})$. In addition, the objective of this experiment was to avoid a confounding effect between the level of energy supply and changes in the nature of materials supplied to cows through isoenergetic treatments (diets plus infusions). Unfortunately, feed intake was depressed with the VFA infusion for the control treatment (Rigout et al., 2003), which might explain the tendency toward a lower milk yield for cows under the control treatment than for those treated with glucogenic materials because of the lower nutrient supplies to the mammary gland. For all these reasons, the present experiment did not indicate whether the increase in $\mathrm{Ra}$ is the key mechanism explaining the increased milk yield. However, the increase of mammary gland net balance of glucose accounted for $60 \%$ of the increase of Ra in a previous experiment of increasing infusions of duodenal glucose from 0 to 2.64/d Mcal of $\mathrm{NE}_{\mathrm{L}}$ (Rigout et al., 2002b) when treatments were isoenergetics. In addition, the bibliographical study showed that isoenergetic infusions of both post-ruminal 
glucose and ruminal C3 leads to a curvilinear increase in milk yield (Hurtaud et al., 2000; Rigout et al., 2003).

In the present experiment, with the high dose of glucose infused into the duodenum, Ra was not a further limiting factor to the increased lactose production and milk yield because the ratio of lactose production to $\mathrm{Ra}$ significantly decreased (0.45) compared with the other treatments (0.54), leading to a significant interaction between duodenal glucose and ruminal C3 treatments. In the previous experiment with duodenal glucose infusions (Rigout et al., 2002b), when a higher dose of glucose was infused $\left(6.6 \mathrm{Mcal} / \mathrm{d}\right.$ of $\left.\mathrm{NE}_{\mathrm{L}}\right)$ than in the present experiment (3.45 Mcal/d of $\mathrm{NE}_{\mathrm{L}}$ ), a change in the partition of glucose utilization between mammary and other tissues was observed because Ra continued to increase but mammary gland net uptake of glucose decreased. In the present experiment, the decrease in the ratio of lactose production to $\mathrm{Ra}$ may reflect a change in the partition of glucose utilization between mammary and other tissue. However, glucose concentration in milk was not decreased with glucose treatment at the high dose compared with $\mathrm{C} 3$ treatment. In the experiment of Rigout et al. (2002b), glucose concentration in milk followed mammary gland net balance of glucose. In addition, lactose production and milk yield did not decrease. This decrease in the ratio of lactose production to Ra may also partially result from a change in the partition of glucose utilization in the mammary gland between lactose synthesis and other utilization. Some mammary glucose might not have only been used for lactose, but might have also been used to generate energy for greater synthesis of NADPH through the pentose phosphate pathway (Rigout et al., 2002a, 2003) because the glucose treatments significantly increased mammary de novo synthesis of medium-chain fatty acids (Rigout et al., 2002a), which was not the case for C3 treatment (Rigout et al., 2003).

In the present experiment, the increased plasma IGFI concentrations observed with both glucogenic materials may also be related to the parallel increases in milk yield and protein yield. The increase in plasma IGF-I concentration was possibly linked to increased blood flow (Bequette et al., 2001; Rigout et al., 2002b). In a previous experiment on duodenal glucose infusions (Rigout et al., 2001, 2002b), the increase in blood flow with a parallel increase in Ra allowed increased mammary gland net uptake of glucose when duodenal glucose infusions ranged from 0 to $2.64 \mathrm{Mcal} / \mathrm{d}$ of $\mathrm{NE}_{\mathrm{L}}$. In addition, it was the only factor explaining the increased EAA uptake by the mammary gland and the increased milk protein yield because EAA concentrations and EAA arterio-venous differences remained unchanged (Rigout et al., 2001). In the present experiment, rumen C3 treatment might have had a similar effect on blood flow in comparison with duodenal glucose because both increased IGF-I concentrations.

\section{CONCLUSIONS}

In the present experiment, when comparing two levels of duodenal glucose and ruminal C3 (1.72 Mcal/d and $3.45 \mathrm{Mcal} / \mathrm{d}$ of $\mathrm{NE}_{\mathrm{L}}$ ) to an isoenergetic control (VFA infusions), only an increase of $3.45 \mathrm{Mcal} \mathrm{NE} / \mathrm{d}$ (6.87 $\mathrm{mol} / \mathrm{d}$ ) of duodenal glucose significantly increased $\mathrm{Ra}$ $(+3.7 \mathrm{~mol} / \mathrm{d})$. Based on the results obtained in the present experiment and in the study of Rigout et al. (2002b), Ra may follow a sigmoidal curve in response to increasing amounts of duodenal glucose. The effect of an isoenergetic infusion of ruminal C3 (3.45 Mcal NE $\mathrm{NE}_{\mathrm{L}} / \mathrm{d} ; 13$ $\mathrm{mol} / \mathrm{d}$ ) on Ra remained unclear, which was due partially to one data measurement that increased the RMSE of the $\mathrm{Ra}$ measurement and was higher than that presented in another experiment (Rigout et al., 2002b). Unfortunately, the present experiment did not indicate whether the increased Ra was a key mechanism explaining the increased milk yield generally observed with increasing supplies of glucogenic nutrients (Rigout et al., 2003) because of the high RMSE obtained for Ra and because in the present experiment milk yield only tended to increase in response to duodenal glucose or ruminal C3. However, the ratio of lactose production to Ra was decreased with the high dose of duodenal glucose infused, suggesting that a greater part of glucose available in blood was used for other metabolic pathways than lactose synthesis. Both glucose and C3 treatments also increased plasma IGF-I concentrations significantly, suggesting that the regulation of glucose and AA utilization by IGF-I may be another important mechanism involved in the increased milk and protein yield.

\section{ACKNOWLEDGMENTS}

Sophie Rigout's Ph.D. grant was supported by Agribrands International. The authors gratefully acknowledge J. L. Peyraud for expert advice and for guidance in the writing of this manuscript. Also special thanks to P. Lamberton and his team for their helpful assistance, care, and feeding of cows; J. N. Thibault (UMR VP, INRA, Saint-Gilles, France) for $\left[6,6-{ }^{2} \mathrm{H}_{2}\right]$ glucose enrichment analyses; C. Morel and Y. Zbinden (Division of Nutritional and Physiology, University of Berne, Switzerland) for analyses of growth hormone, glucagons, and IGF-I; and M. Texier, I. Jicquel, S. Rigault, and M. Ermel for technical assistance. K. Lynch corrected the English manuscript. 


\section{REFERENCES}

Allen, D. M., and R. J. Grant. 2000. Interactions between forage and wet corn gluten feed as sources of fiber in diets for lactating dairy cows. J. Dairy Sci. 83:322-331.

Baird, G. D., M. A. Lomax, H. W. Symonds, and S. R. Shaw. 1980. Net hepatic and splanchnic metabolism of lactate, pyruvate and propionate in dairy cows in vivo in relation to lactation and nutrient supply. Biochem. J. 186:47-57.

Baird, G. D., J. G. Van Der Walt, and E. G. Bergman. 1983. Wholebody glucose and lactate in productive sheep and cows. Biochem. J. 186:47-57.

Bequette, B. J., C. E. Kyle, L. A. Crompton, V. Buchan, and M. D. Hanigan. 2001. Insulin regulates milk production and mammary gland and hind-leg amino acid fluxes and blood flow in lactating goats. J. Dairy Sci. 84:241-255.

Casse, E. A., H. Rulquin, and G. B. Huntington. 1994. Effect of mesenteric vein infusion of propionate on splanchnic metabolism in primiparous Holstein cows. J. Dairy Sci. 77:3296-3303.

Clark, J. H., H. R. Spires, R. G. Derrig, and M. R. Bennink. 1977. Milk production, nitrogen utilization and glucose synthesis in lactating cows infused postruminally with sodium caseinate and glucose. J. Nutr. 107:631-644.

Danfaer, A., V. Tetens, and N. Agergaard. 1995. Review and an experimental study on the physiological and quantitative aspects of gluconeogenesis in lactating ruminants. Comp. Biochem. Physiol. 111B:201-210.

Demigné, C., C. Yacoud, C. Morand, and C. Rémésy. 1991. Interaction between propionate and amino acid metabolism in isolated sheep hepatocytes. Br. J. Nutr. 65:301-317.

Huhtanen, P., A. Vanhatalo, and T. Varvikko. 2002. Effects of abomasal infusions of histidine, glucose, and leucine on milk production and plasma metabolites of dairy cows fed grass silage diets. J. Dairy Sci. 85:204-216.

Huntington, G. B. 1997. Starch utilization by ruminants: from basics to the bunk. J. Anim. Sci. 75:852-867.

Hurtaud, C., S. Lemosquet, and H. Rulquin. 2000. Effect of graded duodenal infusions of glucose on yield and composition of milk from dairy cows. 2. Diets based on grass silage. J. Dairy Sci. 83:2952-2962.

Institut National de la Recherche Agronomique. 1989. Ruminant Nutrition: Recommended Allowances and Feed Tables. R. Jarrige, ed. John Libbey, Eurotext, London, UK.

Judson, G. J., and R. A. Leng. 1973. Studies on the control of gluconeogenesis in sheep: Effect of propionate, casein and butyrate infusions. Br. J. Nutr. 29:175-195.

Knowlton, K. F., T. E. Dawson, B. P. Glenn, G. B. Huntington, and R. A. Erdman. 1998. Glucose metabolism and milk yield of cows infused abomasally or ruminally with starch. J. Dairy Sci. 81:3248-3258.

Kreikemeier, K. K., D. L. Harmon, R. T. Brandt, T. B. Avery, and D. E. Johnson. 1991. Small intestinal starch digestion in steers: effect of various levels of abomasal glucose, corn starch and corn dextrin infusion on small intestinal disappearance and net glucose absorption. J. Anim. Sci. 69:328-338.
Lemosquet, S., N. Rideau, H. Rulquin, P. Faverdin, J. Simon, and R. Vérité. 1997. Effect of a duodenal glucose infusion on the relationship between plasma concentrations of glucose and insulin in dairy cows. J. Dairy Sci. 80:2854-2865.

Lomax, M. A., G. D. Baird, C. B. Mallinson, and H. W. Symonds. 1979. Differences between lactating and non lactating dairy cows in concentration and secretion rate of insulin. Biochem. J. 180:281-289.

Majdoub, L., M. Vermoral, and I. Ortigues-Marty. 2003. Intraruminal propionate supplementation modifies hindlimb energy metabolism without changing the splanchnic release of glucose in growing lambs. Br. J. Nutr. 89:39-50.

Peiris, H., R. Elliott, and B. W. Norton. 1998. Supplementary grain and sodium propionate increase the liveweight gain and glucose entry rates of steers given molasses diets. J. Agric. Sci. (Camb.) 130:205-211.

Piccioli Capelli, F., C. J. Seal, and D. S. Parker. 1997. Glucose and $\left[{ }^{13} \mathrm{C}\right]$ leucine metabolism by the portal-drained viscera of sheep on dried grass with acute intravenous and intraduodenal infusions of glucose. Br. J. Nutr. 78:931-946.

Reynolds, C. K., D. J. Humphries, S. B. Cammell, J. Benson, J. D. Sutton, and D. E. Beever. 1997. Effects of abomasal wheat starch infusion on splanchnic metabolism and energy balance of lactating dairy cows. Pages 39-42 in Energy Metabolism of Farm Animals. Proc. 14th Symp. Energy Metab., Newcastle, Co. Down, Northern Ireland. CAB Int., London, UK.

Rigout, S., C. Hurtaud, S. Lemosquet, A. Bach, and H. Rulquin. 2003. Lactational effect of propionic acid and duodenal glucose in cows. J. Dairy Sci. 86:243-253.

Rigout, S., S. Lemosquet, A. Bach, J. W. Blum, and H. Rulquin. 2002a. Duodenal glucose decreases milk fat production in grass silagefed dairy cows. J. Dairy Sci. 85:2541-2550.

Rigout, S., S. Lemosquet, J. W. Blum, and H. Rulquin. 2001. Effects of glucose on milk protein synthesis in lactating dairy cows. Livest. Prod. Sci. 70:175.(Abstr.).

Rigout, S., S. Lemosquet, J. E. Van Eys, J. W. Blum, and H. Rulquin $2002 \mathrm{~b}$. Duodenal glucose increases glucose fluxes and lactose synthesis in grass silage-fed dairy cows. J. Dairy Sci. 85:595-606.

Rulquin, H., 1981. Etude méthodologique sur la mesure des différences artério-veineuses mammaires chez la vache laitière. Reprod. Nutr. Develop. 21:31-46.

Rulquin, H., R. Vérité, and J. Guinard-Flament. 2001. Amino acids truly digestible in the small intestine: the AADI system for the dairy cows. INRA Prod. Anim. 14:265-274.

SAS User's Guide: Statistics, Version 6. Edition 4. 1990. SAS Inst., Inc., Cary, NC.

Seal, C. J., and D. S. Parker. 1994. Effect of intraruminal propionic acid infusion on metabolism of mesenteric- and portal-drained viscera in growing steers fed a forage diet: 1 . Volatile fatty acids, glucose, and lactate. J. Anim. Sci. 72:1325-1334.

Veenhuizen, J. J., R. W. Russell, and J. W. Young. 1988. Kinetics of metabolism of glucose, propionate and $\mathrm{CO}_{2}$ in steers as affected by injecting phlorizin and feeding propionate. J. Nutr. 118:1366-1375.

Wieghart, M., R. Slepetis, J. M. Elliot, and D. F. Smith. 1986. Glucose absorption and hepatic gluconeogenesis in dairy cows fed diets varying in forage content. J. Nutr. 116:839-850. 